BACKGROUND: Ozone therapy has become a useful treatment for pathological processes, in which the damage mediated by reactive oxygen species is involved. Several lines of evidence suggest that cisplatin-induced acute nephrotoxicity is partially mediated by reactive oxygen species.

Aims: To analyze the effect of ozone administration after cisplatin-induced acute nephrotoxicity.

Methods: Male Sprague-Dawley rats were treated with five intra-rectal applications of ozone/oxygen mixture at $0.36,1.1$ and $1.8 \mathrm{mg} / \mathrm{kg}$ after cisplatin intraperitoneal injection $(6 \mathrm{mg} / \mathrm{kg})$. Serum and kidneys were taken off 5 days after cisplatin treatment. Creatinine was measured in the serum and the activities of antioxidant enzymes and thiobarbituric acid reactive substances and glutathione content were analyzed in renal homogenate.

Results: Ozone treatment diminished the increase in serum creatinine levels, the glutathione depletion and also reversed the inhibition of superoxide dismutase, catalase and glutathione peroxidase activities induced by cisplatin in the rat kidney. Also, the renal content of thiobarbituric reactive substances was decreased by ozone/oxygen mixture applied after cisplatin.

Conclusion: Intrarectal applications of ozone reversed the renal pro-oxidant unbalance induced by cisplatin treatment by the way of stimulation to some constituents of antioxidant system in the kidney, and thereby it decreased the renal damage.

\section{Reversion by ozone treatment of acute nephrotoxicity induced by cisplatin in rats}

\author{
Ricardo González , Aluet Borrego ${ }^{1, C A}$, \\ Zullyt Zamora ${ }^{1}$, Cheyla Romay ${ }^{1}$, Frank Hernández ${ }^{1}$, \\ Silvia Menéndez ${ }^{1}$, Teresita Montero ${ }^{2}$ and \\ Enis Rojas ${ }^{1}$
}

${ }^{1}$ Ozone Research Center, PO Box 6414, Cuba; ${ }^{2 ` D r}$ Luis Díaz Soto' Hospital, Cuba

\section{Introduction}

Cisplatin (CDDP) is one of the most effective chemotherapeutic agents for the treatment of ovarian, testicular and bladder carcinomas, and cancers of the head and neck and lung. ${ }^{1}$ Unfortunately, more than $25 \%$ of patients receiving an initial dose $\left(50-100 \mathrm{mg} / \mathrm{m}^{2}\right)$ of CDDP develop acute renal failure ${ }^{1}$ due to its preferential accumulation within the proximal tubule cells in the outer medulla of the kidney. ${ }^{2}$ The cellular events in CDDP-induced acute nephrotoxicity, including decreased protein synthesis, membrane lipid peroxidation, mitochondrial dysfunction and DNA injury, are a consequence of free radical generation and the inability to scavenge such molecules. ${ }^{3}$ Furthermore, various studies have demonstrated a protective role for antioxidants and free radical scavengers such as vitamin E, lipoic acid, ebselen, superoxide dismutase (SOD), taurine, glutathione (GSH) and its esters in CDDP-induced acute nephrotoxicity. ${ }^{4-9}$

Very recently, studies from our laboratory have demonstrated that ozone $\left(\mathrm{O}_{3}\right)$ pretreatment under an oxidative preconditioning regimen for 15 days exerts protection against CDDP-induced acute renal damage in rats, and it was due to the $\mathrm{O}_{3}$ protective effects on some important constituents of the antioxidant system in the kidney such as SOD, catalase (CAT), glutathione peroxidase (GSH$\mathrm{Px}), \mathrm{GSH}$, and the concomitant reduction of renal lipid peroxidation. ${ }^{10}$ Taking into account these findings we decided to elucidate whether ozone therapy administered after CDDP-induced acute nephrotoxicity is able to reverse it.

\section{Materials and methods}

\section{Chemicals}

Serum creatinine was measured spectrophotometrically with the creatinine assay kits purchased from Biological Products Enterprise 'Carlos J Finlay' (Havana, Cuba). All reagents used in determinations of GSH, SOD, CAT, GSH-Px, thiobarbituric acid reactive substances (TBARS) and cisplatin were purchased from Sigma Chemicals (St Louis, MO, USA). Other reagents of analytical grade were obtained from normal commercial sources. 


\section{Animals}

Male Sprague-Dawley rats (200-250 g) were obtained from the National Center for Laboratory Animal Production (CENPALAB, Havana Cuba). The animals were housed under a $12 \mathrm{~h}$ light-dark cycle with room temperature maintained at $25^{\circ} \mathrm{C}$, humidity at $60 \%$ and food and water available ad libitum. The experiments were conducted in accordance with the ethical guidelines for investigations in laboratory animals and were approved by the Ethical Committee for Animal Experimentation of the National Center for Scientific Research, Havana, Cuba.

\section{Experimental design}

An ozone/oxygen mixture (OOM) was generated by OZOMED 01 equipment manufactured by the Ozone Research Center (Cuba). The OOM was obtained from medical-grade oxygen and it was used immediately. The $\mathrm{O}_{3}$ concentration was measured by an ultraviolet spectrophotometer at $254 \mathrm{~nm}$.

The rats were divided into six groups of eight rats each: (1) non-treated control rats, (2) rats treated only with CDDP, (3) rats treated with CDDP plus oxygen $\left(\mathrm{O}_{2}\right)$, (4) rats treated with CDDP plus OOM (10 $\mu \mathrm{g}$ of $\mathrm{O}_{3} / \mathrm{ml}$ at a dose of $0.36 \mathrm{mg} / \mathrm{kg}$ ), (5) rats treated with CDDP plus OOM (30 $\mu \mathrm{g}$ of $\mathrm{O}_{3} / \mathrm{ml}$ at a dose of 1.1 $\mathrm{mg} / \mathrm{kg}$ ), and (6) rats treated with CDDP plus OOM (50 $\mu \mathrm{g}$ of $\mathrm{O}_{3} / \mathrm{ml}$ at a dose of $1.8 \mathrm{mg} / \mathrm{kg}$ ).

CDDP (6 mg/kg) was administered to rats by an intraperitoneal injection and thereafter OOM was administered once daily by rectal insufflation during 5 days. The volume of insufflated mixture was approximately $9 \mathrm{ml}$.

Twenty-four hours after the last OOM application the rats were killed by ether overdose, and afterwards the blood was collected and serum was separated by centrifugation for creatinine analysis. The kidneys

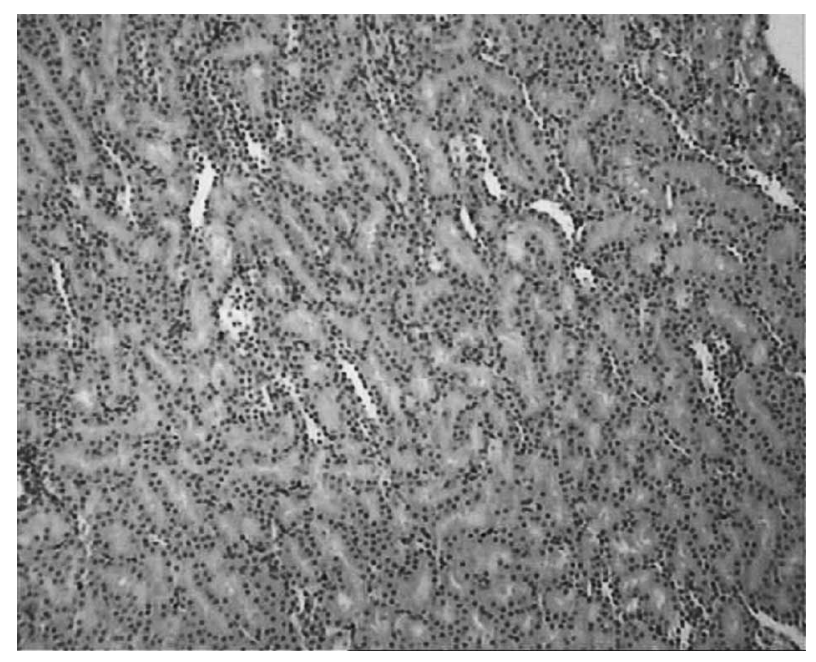

FIG. 1. Light micrograph of the corticomedulary region of a rat kidney from the control group. Normal histology (hematoxylin and eosin, $\times 100$ ). were removed and immediately frozen at $-20^{\circ} \mathrm{C}$ until biochemical and histopathological studies were performed.

Kidney homogenates were obtained using a tissue homogenator at $4^{\circ} \mathrm{C}$. The homogenates were prepared with a $100 \mathrm{mM} \mathrm{KCl}$ buffer ( $\mathrm{pH}$ 7) containing ethylenediamine tetraacetic acid $0.3 \mathrm{mM}(1: 10 \mathrm{w} / \mathrm{v})$ for GSH, TBARS, GSH-Px and SOD determinations (Buffer 1). The homogenates were spun down with a centrifuge at $600 \times \mathrm{g}$ for $60 \mathrm{~min}$ at $4^{\circ} \mathrm{C}$. The supernatants were taken for biochemical determinations.

Kidney homogenates for CAT enzymatic assay were obtained with a $50 \mathrm{mM}$ phosphate buffer $(\mathrm{pH}$ 7) containing $1 \%$ Triton X-100 $(1: 9 \mathrm{w} / \mathrm{v})$ (Buffer 2 ). The homogenates were centrifuged at $600 \times g$ for 60 $\min$ at $4{ }^{\circ} \mathrm{C}$ and the supernatants were used for the CAT assay.

\section{Determination of GSH}

GSH was determined by a slightly modified version of the method of Beutler et al., ${ }^{11}$ using a spectrophotometer. One milliliter of the kidney homogenate, as already described, was mixed with $1.5 \mathrm{ml}$ of $5 \%$ metaphosphoric acid and centrifuged at $3000 \times g$ for $10 \mathrm{~min}$ at room temperature. Five hundred microliters of this acidic supernatant was mixed with $2 \mathrm{ml}$ of 0.2 $\mathrm{M}$ phosphate buffer and $0.25 \mathrm{ml}$ of $0.04 \% 5,5^{\prime}$-dithiobis-2-nitrobenzoic acid. Absorbance of the yellow solution was measured at $412 \mathrm{~nm}$ within $10 \mathrm{~min}$. A molar extinction coefficient of $13.6 \mathrm{M} / \mathrm{cm}$ that describes the formation of the thiolate anion by the reaction of sulfhydryl groups with 5,5'-dithio-bis-2nitrobenzoic acid at $412 \mathrm{~nm}$ was used to quantify GSH.

\section{Determination of SOD}

The enzymatic activity of SOD was determined by a modified version of the method of Minami and Yoshikawa. ${ }^{12}$ Fifty microliters of the kidney homogenate was mixed with $450 \mu \mathrm{l}$ of cold deionized water, $125 \mu \mathrm{l}$ of chloroform and $250 \mu \mathrm{l}$ of ethanol. The mixture was centrifuged at $8000 \times g$ for $2 \mathrm{~min}$ at $4{ }^{\circ} \mathrm{C}$. Five hundred microliters of the extract was added to a reaction mixture containing $500 \mu \mathrm{l}$ of $72.4 \mathrm{mM}$ Tris-Cacodylate buffer with $3.5 \mathrm{mM}$ diethylene pentaacetic acid ( $\mathrm{pH}$ 8.2), $100 \mu \mathrm{l}$ of $16 \%$ Triton-X 100 and $250 \mu \mathrm{l}$ of $0.9 \mathrm{mM}$ nitro-blue tetrazolium. The reaction mixture was incubated for $5 \mathrm{~min}$ at $37^{\circ} \mathrm{C}$ before adding $10 \mu \mathrm{l}$ of $9 \mathrm{mM}$ pyrogallol (dissolved in $10 \mathrm{mM}$ hydrochloric acid), and then incubated for $5 \mathrm{~min}$ at $37^{\circ} \mathrm{C}$. The reaction was stopped with the addition of $300 \mu \mathrm{l}$ of $2 \mathrm{M}$ formic buffer ( $\mathrm{pH} 3.5$ ) containing 16\% Triton-X 100. The absorbance was measured at $540 \mathrm{~nm}$ on the spectrophotometer. One unit of SOD enzymatic activity is 
equal to the amount of enzyme that diminishes the initial absorbance of nitro-blue tetrazolium by $50 \%$.

\section{Determination of CAT}

CAT was determined according to the method of Rice Evans and Diplock. ${ }^{13}$ Kidney homogenate was diluted with Buffer 2, as already described, to obtain an adequate dilution of the enzyme. Then, $2 \mathrm{ml}$ of buffer 2 were added to the cuvette and mixed with $1 \mathrm{ml}$ of $30 \mathrm{mM} \mathrm{H}_{2} \mathrm{O}_{2}$, and then the absorbance was measured at $240 \mathrm{~nm}$, for $30 \mathrm{sec}$ in the spectrophotometer. The initial absorbance of the reaction mixture must be around 0.5 . The enzyme activity is expressed as the first-order constant that describes the decomposition of $\mathrm{H}_{2} \mathrm{O}_{2}$ at room temperature.

\section{Determination of GSH-Px}

The enzymatic activity of GSH-Px was determined using a modified version of the method of Thonson et al. ${ }^{14}$ All reaction mixtures were dissolved in $20 \mathrm{mM}$ sodium phosphate buffer containing $6 \mathrm{mM}$ ethylenediamine tetraacetic acid $(\mathrm{pH} 7.0)$. The reaction mixture consisted of $98.8 \mu$ l of phosphate buffer, $700 \mu \mathrm{l}$ of $2.86 \mathrm{mM} \mathrm{GSH}, 100 \mu \mathrm{l}$ of $1 \mathrm{mM}$ sodium azide, $100 \mu \mathrm{l}$ of $1 \mathrm{mM}$ NADPH and $4.2 \mu \mathrm{l}$ of GSH reductase (0.5 units). Then, $10 \mu \mathrm{l}$ of the tissue homogenate supernantant were added to the reaction mixture and incubated at room temperature for 10-15 $\mathrm{min}$. Afterwards, $10 \mu \mathrm{l}$ of $30 \mathrm{mM} t$-butyl hydroperoxide (dissolved in bi-distilled water) was added to the reaction mixture and measured at $340 \mathrm{~nm}$ for $7 \mathrm{~min}$ in the spectrophotometer. A molar extinction coefficient of $6.22 \times 10^{3} \mathrm{M} / \mathrm{cm}$ was used to determine the activity of GSH-Px. The enzyme activity is expressed as international units of enzymatic activity/milligram of protein. International units are expressed as micromoles of transformed hydroperoxides per minute per milliliter of enzyme.

\section{Lipid peroxidation assay}

This assay is used to determine TBARS levels as described by Ohkawa et al. ${ }^{15}$ Two hundred milliliters of tissue homogenate supernatant were added to 100 $\mu \mathrm{l}$ of sodium dodecyl sulfate, $750 \mu \mathrm{l}$ of $20 \%$ acetic acid ( $\mathrm{pH} 3.5), 750 \mu \mathrm{l}$ of $0.6 \%$ thiobarbituric acid and $300 \mu \mathrm{l}$ of distilled water and were incubated at $95^{\circ} \mathrm{C}$ for $60 \mathrm{~min}$. The samples were allowed to cool at room temperature. Then $2.5 \mathrm{ml}$ of butanol:pyridine (15:1) and $500 \mu \mathrm{l}$ of distilled water were added, vortexed, and centrifuged at $2000 \times g$ for $15 \mathrm{~min}$. The absorbance of $3 \mathrm{ml}$ of the colored layer was measured at $532 \mathrm{~nm}$ spectrophotometrically using 1,1,3,3-tetraethoxypropane as the standard.

\section{Protein assay}

Protein concentrations were determined by the method of Lowry et al. ${ }^{16}$ using bovine serum albumin as standard.

\section{Histopathological assessment of renal damage}

The left kidneys were quickly removed and fixed in $10 \%$ formaldehyde. Tissues were embedded in paraffin, sectioned at $3 \mu \mathrm{m}$, stained with hematoxylin and eosin and evaluated by light microscopy.

\section{Statistical analysis}

Data are expressed as the mean \pm standard error of the mean and analyzed statistically using one-way analysis of variance followed by the Duncan multiple range test for serum creatinine determinations, whereas the Kruskall-Wallis test followed by the Mann-Whitney test was applied for the rest of the markers. The 0.05 level of probability was used as statistical significance.

\section{Results}

Serum creatinine levels significantly increased in CDDP-injected rats as compared with non-treated control $(p<0.01)$. Graded doses of $\operatorname{OOM}(0.36,1.1$ and $1.8 \mathrm{mg} / \mathrm{kg}$ ) significantly reduced in $50 \%$ the increase of serum creatinine levels as compared with CDDP alone and CDDP plus $\mathrm{O}_{2}$, indicating that $\mathrm{O}_{3}$ treatment ameliorated the nephrotoxicity of CDDP (Table 1)

Also, $\mathrm{O}_{3}$ treatment induced reversion of the renal GSH depletion induced by CDDP. This effect was significantly greater at an $\mathrm{O}_{3}$ dose of $1.1 \mathrm{mg} / \mathrm{kg}$ as compared with CDDP-treated or non-treated rats. In agreement with that finding, the OOM significantly reduced, the renal TBARS content at an $\mathrm{O}_{3}$ dose of $1.1 \mathrm{mg} / \mathrm{kg}$, although the other two tested doses did not induce any significant change with respect to CDDP-treated control rats.

The SOD activity in the kidney significantly decreased ( $44 \%$ of control) in CDDP-treated rats. The treatment with OOM induced reversion of SOD activity up to values very close to those of the non-treated control group. Thus, $\mathrm{O}_{3}$ treatment exerted a stimulating effect in renal SOD activity as compared with CDDP alone. This effect was dose dependent.

CAT activity in the kidney significantly decreased ( $48 \%$ of control) in CDDP-treated rats as compared with the control group. The treatment with OOM induced also in a dose-dependent fashion a significant reversion of that effect. The increase of renal CAT activity by $\mathrm{O}_{3}$ treatment was greater with doses 


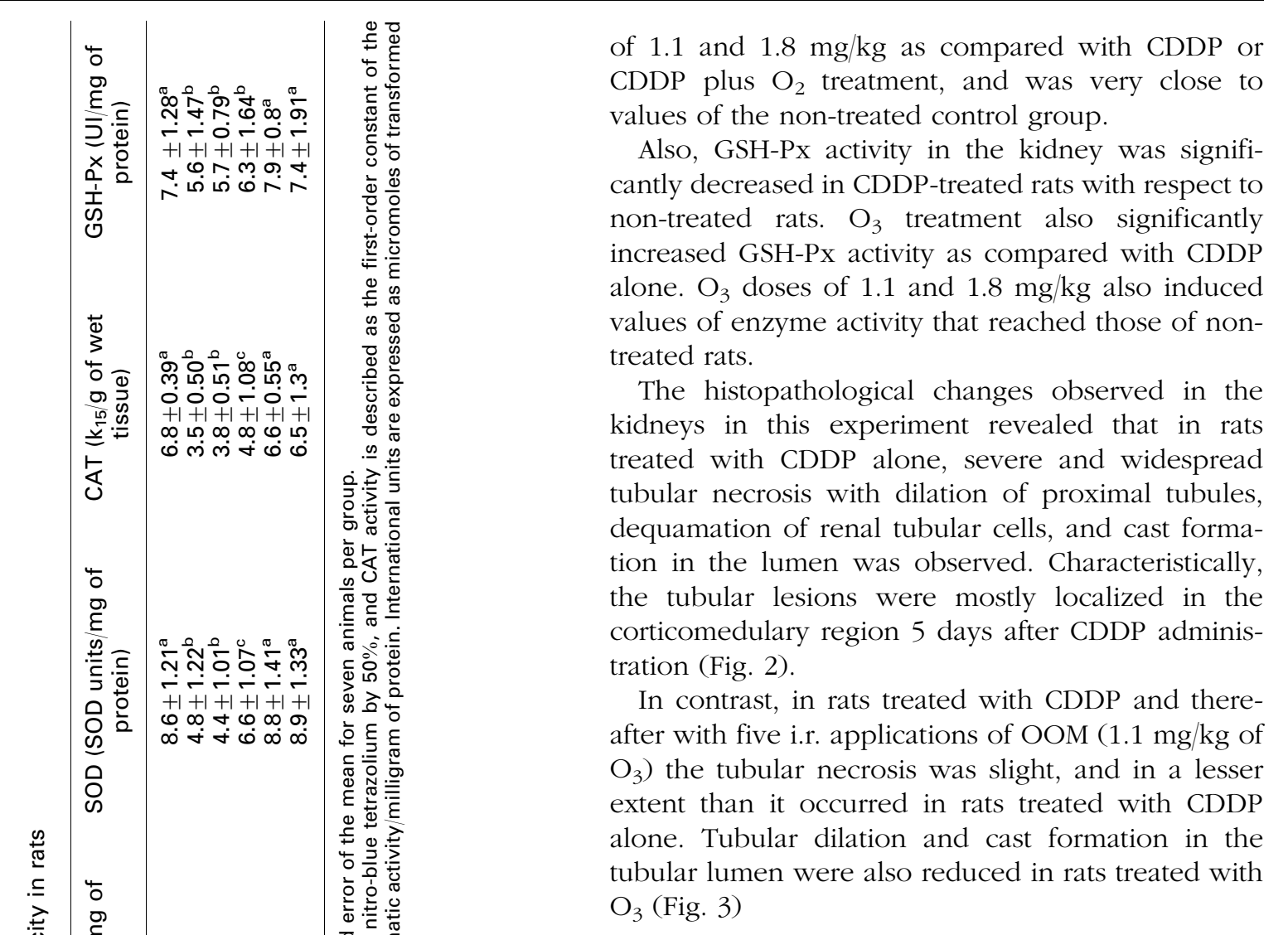

\section{Discussion}

To date different strategies have been proposed to inhibit CDDP-induced nephrotoxicity. One of them is the use of antioxidant therapies to prevent the generation of reactive oxygen species, which exert

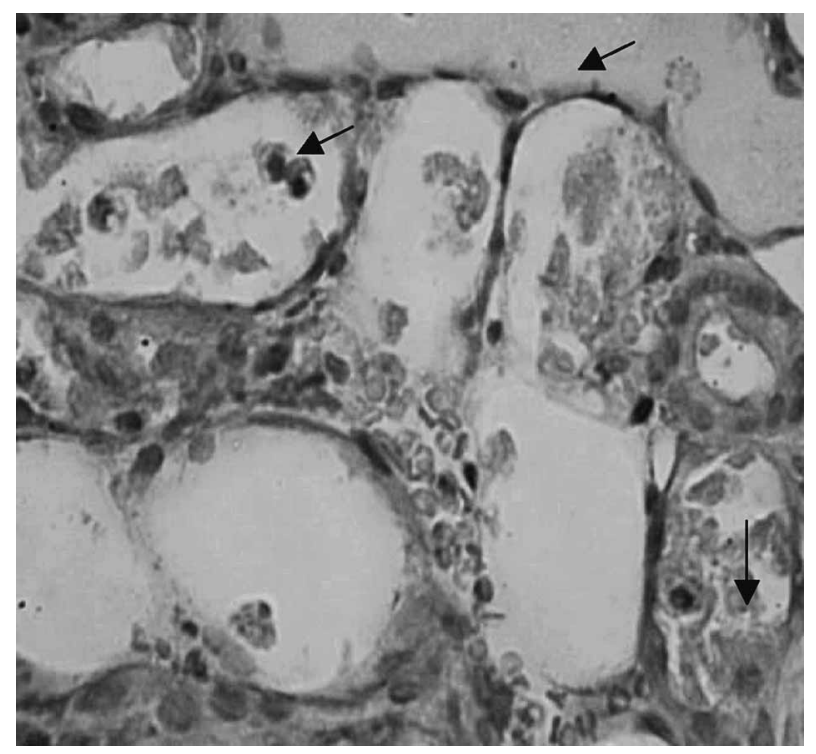

FIG. 2. Light micrograph of the corticomedulary region of a rat kidney treated with CDDP alone. Typical severe tubular necrosis with dilation of proximal tubules is shown. Arrows indicate dequamation of renal tubular cells and cast formation in the tubular lumen (hematoxylin and eosin, $\times 400$ ). 


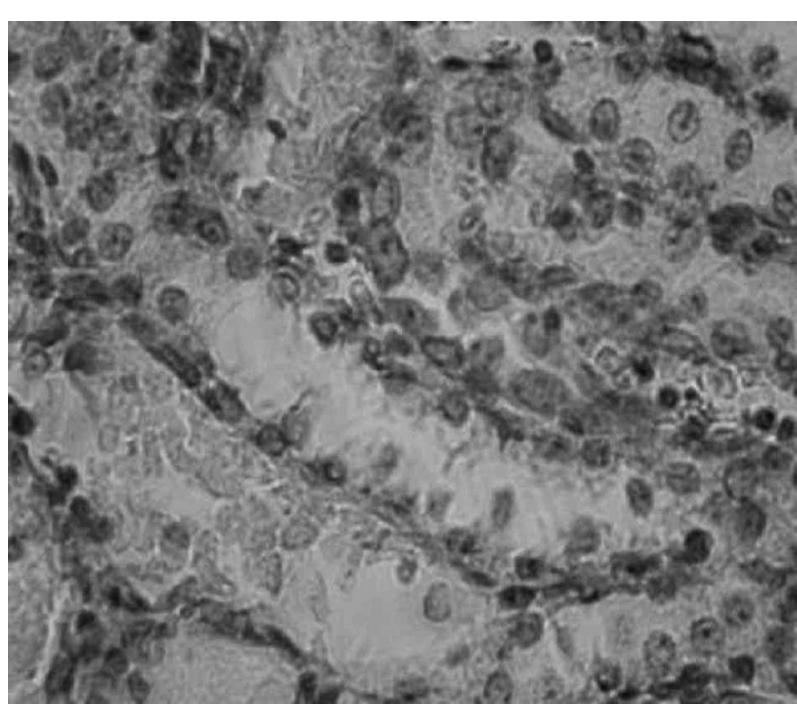

FIG. 3. Light micrograph of the corticomedulary region of a rat kidney treated with OOM after CDDP injection. Tubular necrosis was slight and in lesser extent than in Fig. 2. Note the significant diminution in the dequamation of tubular epithelial cells (hematoxylin and eosin, $\times 400$ ).

an influence on the progression of oxidative renal damage induced by CDDP. ${ }^{17}$ Thus, a proposal has been the use of enriched diets with natural antioxidants like vitamin E, ascorbic acid and methionine among others. ${ }^{4,18}$ Another proposal has been the use of sulfhydryl-containing drugs such as diethyldithiocarbamate, sodium thiosulfate, N-acetylcysteine and lipoic acid, which also exert antioxidant activity. ${ }^{5}$

However, although in animal models all these compounds have shown protective effects in CDDP-induced acute nephrotoxicity, none of them has proved to be clinically efficacious as a complete protective agent in patients. ${ }^{5}$

Very recently, it was demonstrated in our laboratory that $\mathrm{O}_{3}$ pretreatment under an oxidative preconditioning regimen for 15 days exerted protective effects on some important constituents of the endogenous antioxidant system in the kidney such as SOD, CAT, GSH-Px and GSH in CDDP-induced acute nephrotoxicity. ${ }^{10}$ Our present results also demonstrate that i.r. $\mathrm{O}_{3}$ therapy for 5 days after CDDP administration attenuates its nephrotoxicity and also restores the levels of antioxidant defense constituents (GSH, SOD, CAT and GSH-Px) depressed by CDDP up to values close to those of non-treated control rats (Table 1).

Furthermore, the stimulant effects of $\mathrm{O}_{3}$ therapy on antioxidant system were accompanied by a decrease in both serum creatinine levels and renal TBARS content, the latter used as marker of lipid peroxidation in the kidney. Thus, all these aforementioned effects of $\mathrm{O}_{3}$ explain by which mechanisms attenuated acute renal damage is induced by CDDP.
Induction of CAT, SOD and GSH-Px by ozone therapy is probably due to $\mathrm{H}_{2} \mathrm{O}_{2}$ produced as result of $\mathrm{O}_{3}$ decomposition, because it is one of the major $\mathrm{O}_{3}$ intermediates along with $\mathrm{OH}^{*}$ and $\mathrm{O}^{2}$. Whiteside and Hassan $^{19}$ also demonstrated induction of CAT and SOD by $\mathrm{O}_{3}$ in cultures of Escherichia coli. Furthermore, they showed that an increase in the activities of CAT and SOD by $\mathrm{O}_{3}$ was due to induction of the novo enzyme synthesis rather than activation of pre-existing apoproteins.

Induction of CAT and SOD might be related with activation of gene/regulatory nuclear factor-kappa $\mathrm{B}$ (NF- $\kappa B$ ) by $\mathrm{H}_{2} \mathrm{O}_{2}$. This transcription factor appears to play many roles in stress responses, inflammation, cell cycle regulation and apoptosis, ${ }^{20}$ and it has been closely related with the release of cytokines after ozonation of blood ex vivo. ${ }^{21}$ However, we found no nuclear expression of NF- $\mathrm{KB} 5$ days after cisplatin injection in rats (unpublished results), which might suggest that NF- $\mathrm{KB}$ is not directly related with the induction of antioxidant enzymes observed in this experiment, but may be influencing the diminution in inflammatory responses induced by this drug in renal tissue $^{22}$ detected after the fifth day in ozone-treated rats previously injected with cisplatin (unpublished data).

Other proteins that might be involved in ozoneinduced recovery in cisplatin nephropathy are the Bcl-2 family of proto-oncogenes (unpublished results). Within 5 days after cisplatin administration, levels of pro-apoptotic Bax mRNA were significantly increased, as reported by other authors, ${ }^{23}$ and we detected a significant decrease in the expression of this protein with five applications of ozone after cisplatin injection, which is correlated with an increase in the expression of $\mathrm{Bcl} / \mathrm{X}_{\mathrm{L}}$ (unpublished data), favoring the survival and regeneration of the renal tissue.

Thus, the induction of SOD, CAT and GSH-Px in response to $\mathrm{O}_{3}$ treatment in CDDP-induced nephrotoxicity provides further evidence that there is a correlation between antioxidant enzyme biosynthesis and $\mathrm{O}_{3}$ exposure, which supports the potential usefulness of this therapy in the prevention and treatment of this toxic nephropathy.

Rectal insufflation of $\mathrm{O}_{3}$ is a simple procedure and it was reported free of side effects in humans; however, the accurate measurement of the $\mathrm{O}_{3}$ dosage is difficult to assess, ${ }^{24}$ although it is the most useful and easy method to perform in rats. Autohemotherapy, in which a volume of blood is extracted and exposed to a precise ozone dose, represents the most suitable method of application in humans, because there is a reasonable stoichiometric relationship between $\mathrm{O}_{3}$ and blood. ${ }^{25}$ Therefore, autohemotherapy might be promissory for the treatment of cisplatin nephrotoxicity. 


\section{References}

1. Lebwohl D, Canetta R.Clinical development of platinum complexes in cancer therapy: an historical perspective and an update Eur I Cancer 1998; 34 .

2. Safirstein R, Winston J, Moel D.Cisplatin nephrotoxicity: insights into mechanisms Am J Kidney Dis 1986; 8

3. Baliga R, Ueda N, Walker PD.Oxidant mechanisms in toxic acute renal failure Am J Kidney Dis 1997; 29.

4. Appenroth D, Frob S, Kersten L, Splinter FK, Winnefeld K.Protective effect of vitamin $\mathrm{E}$ and $\mathrm{C}$ on cisplatin nephrotoxicity in developing rats Arch Toxicol 1997; 71.

5. Somani SM, Husain K, Whitworth C, Rybak LP.Dose-dependent protection by lipoic acid against cisplatin-induced nephrotoxicity in rats: antioxidant defense system Pharmacol Toxicol 2000; 86

6. Hussain KC, Morris C, Whitworth GL.Protection by ebselen against cisplatin-induced nephrotoxicity: antioxidant system $\mathrm{Mol}$ Cell Biochem $1998 ; \mathbf{1 7 8}$

7. Davis CA, Nick HS, Agarwal A.Manganese superoxide dismutase attenuates cisplatin-induced renal injury: importance of superoxide $J$ Am Soc Nephrol 2001; 12

8. Saad SY, Al-Eikabi AC.Protection effects of taurine supplementation against cisplatin-induced nephrotoxicity in rats Chemotherapy 2002; 48

9. Babu E, Gopal Krishman V, Sriganth IN.Cisplatin induced nephrotoxicity and the modulating effect of glutathione esters Mol Cell Biochem 1995; 144 .

10. Borrego A, Zamora ZB, González $\mathrm{R}$ et al. Protection by ozone preconditioning is mediated by antioxidant system in cisplatin-induced nephrotoxicity in rats. Mediat Inflamm 2004; 13 (in press).

11. Beutler F, Duron O, Mikus B.Improved method for the determination of blood glutathione J Lab Clin Med 1963; 16

12. Minami M, Yoshikawa H.A simplified assay method of superoxide dismutase activity for clinical use Clin Chim Acta 1979; 92.

13. Rice Evans C, Diplock AT.Laboratory techniques in biochemistry and molecular biology In: Burtin RH, Knippenberg PH, eds. Techniques in Free Radical Research.
14. Faraji B, Kang HK, Valentine JL.Methods for determining glutathione peroxidase activity in blood Clin Chem 1987; 33.

15. Ohkawa H, Orishi N, Yagi K.Assay for lipid peroxidation in animals and tissues by thiobarbituric acid reaction Anal Biochem 1979; 95.

16. Lowry $\mathrm{OH}$, Rosebrough NJ, Farr AL, Randall RJ.Protein measurement with the Folin phenol reagent J Biol Chem 1951; 193

17. Bogin E, Maron M, Levi Y.Changes in serum, liver and kidneys of cisplatin-treated rats: effects of antioxidants Eur J Clin Chem Clin Biochem 1994; 32

18. Basinger MAS, Jones MM, Holscher MA.L-methionine antagonism of cisplatinum-induced nephrotoxicity Toxicol Appl Pharmacol 1990; 103.

19. Whiteside C, Hassan HM.Induction and inactivation of catalase and superoxide dismutase of Escherichia coli by ozone Arch Biochem Biophys 1987; 257.

20. Li N, Karin L.Is NF-kB the sensor of oxidative stress? FASEB J 1999; 13.

21. Bocci V, Luzzi E, Corradeschi F, Paulesu L, Di Stefano A.Studies on the biological effects of ozone: 3 . An attempt to define conditions for optimal induction of cytokines Lymph Cyt Res 1993; 12

22. Ramesh G, Reeves WB.TNF alpha mediates chemokine and cytokine expresión and renal injury in cisplatin nephrotoxicity J Clin Invest 2002; 110

23. Sheikh-Hamad D, Cacini W, Buckley AR, Isaac J, Truong LD, Chui Tsao $\mathrm{C}$, Kishore BK.Cellular and molecular studies on cisplatin-induced apoptotic cell death in rat kidney Arch Toxicol 2004; 78.

24. Carpendale MT, Freeberg J, McLeod G. Does ozone alleviate AIDS diarrhea. I Clin Gastroenterol 1993; 142-145.

25. Bocci V.Is ozone therapy therapeutic? Perspect Biol Med 1998; 42, 1998 : $131-140$

\section{Received 27 April 2004 \\ Accepted 7 July 2004}




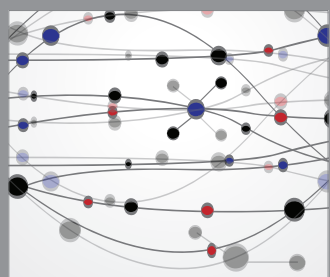

The Scientific World Journal
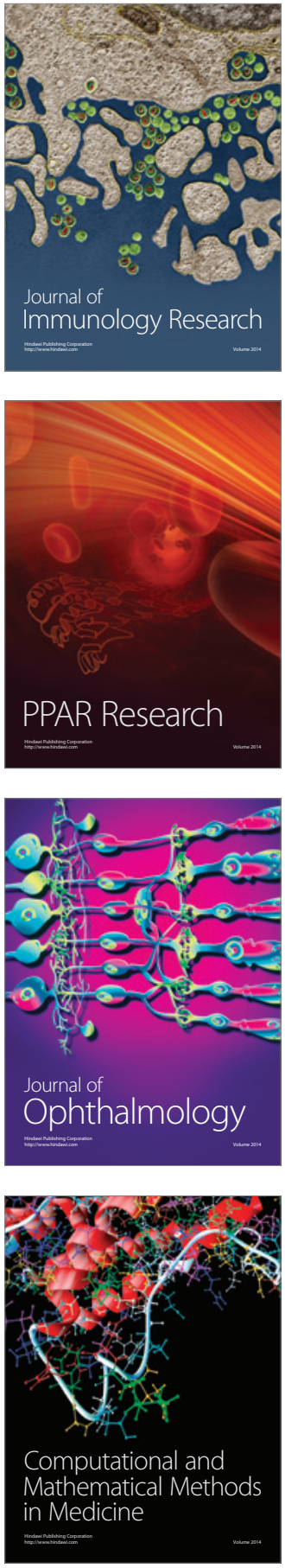

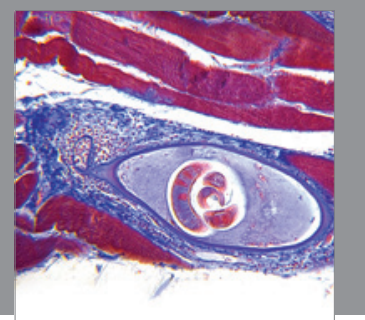

Gastroenterology

Research and Practice
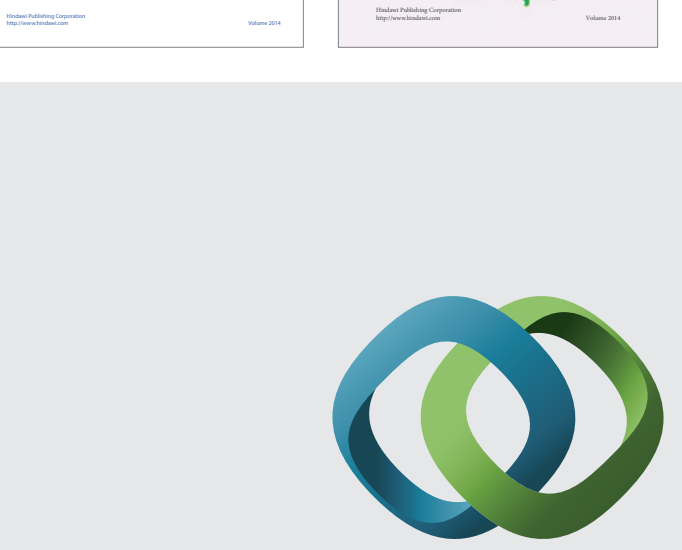

\section{Hindawi}

Submit your manuscripts at

http://www.hindawi.com
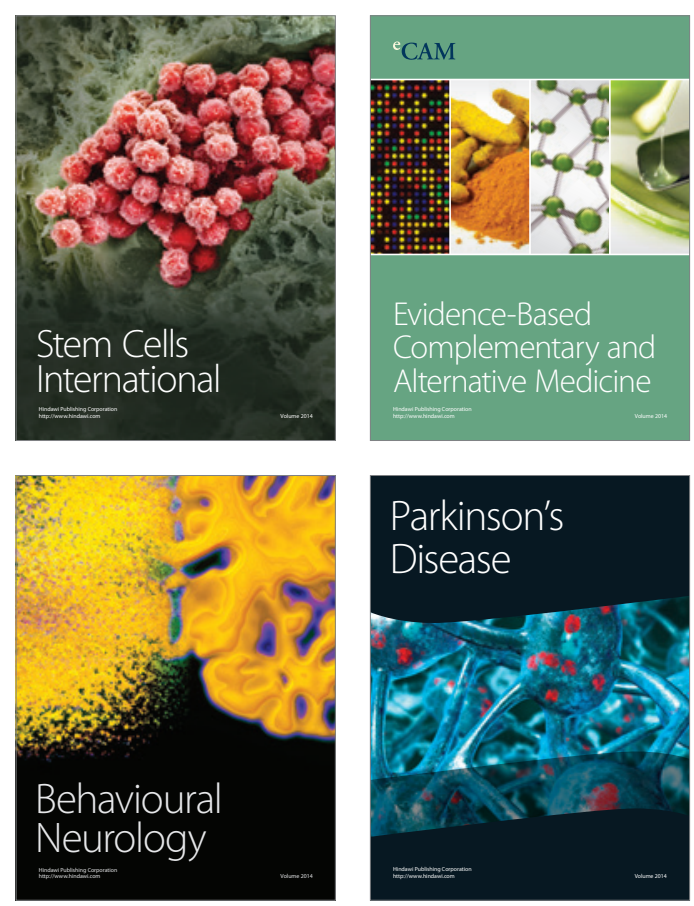

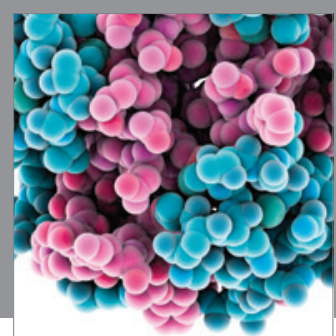

Journal of
Diabetes Research

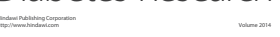

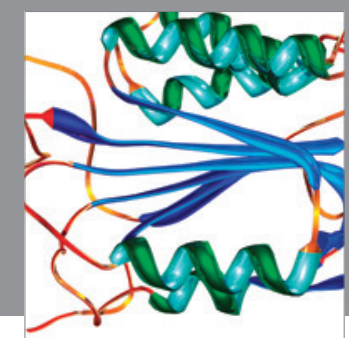

Disease Markers
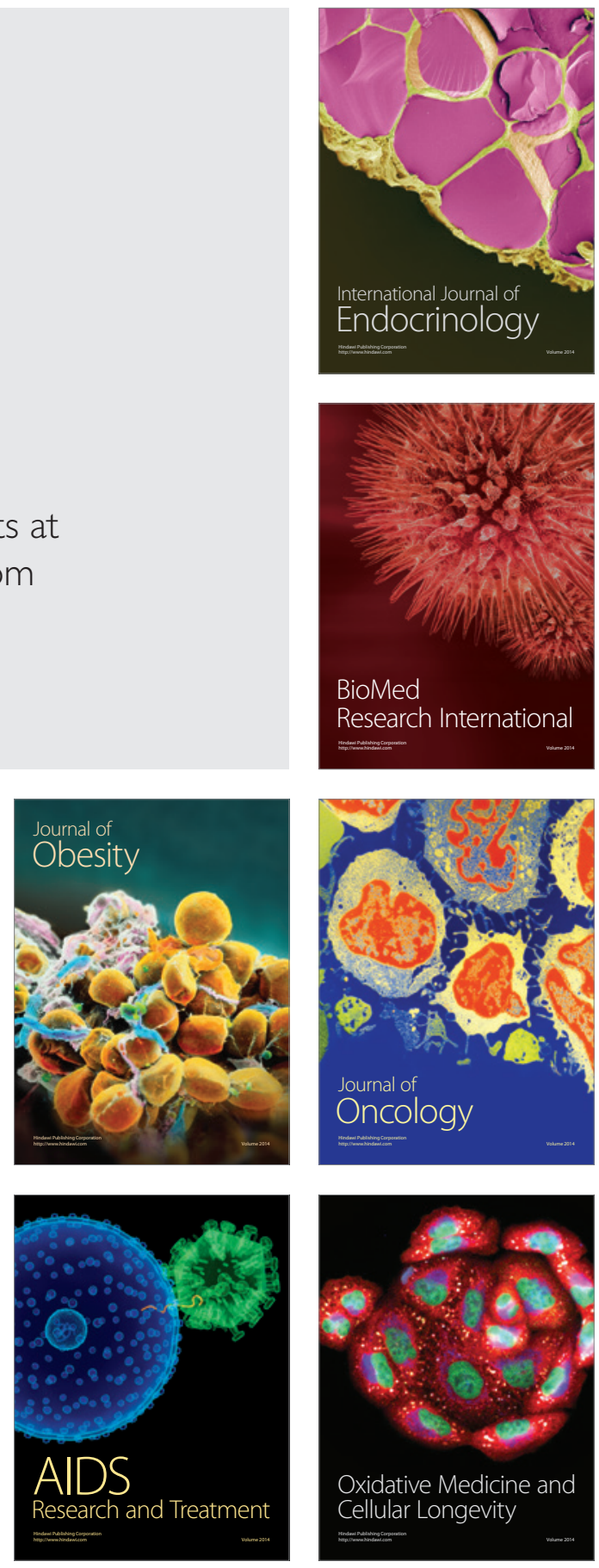